Dig. Surg. 1984;1:I-IV

\title{
Contents, Vol. 1, 1984
}

\section{No. 1}

No. 2-3

Editorial

Original Paper

Experience with the EEA Stapler for Colorectal Anastomosis:

Early and Late Results

Detry, R.; Kestens, P.J.; Secchi, M 2

The Influence of Sucralfate or Cimetidine on Gastric Juice $\mathrm{pH}$,

Bacterial Flora and Mutagenicity

Morris, D.L.; Youngs, D.; Burdon, D.W.; Keighley, M.R.B. 6 Immediate Transduodenal

Sphincteroplasty for Acute Biliary

Pancreatitis

Stone, H.H 10

Results of a Prospective Randomized Double-Blind Trial of

Aprotinin (Trasylol) in Colonic Surgery

Young, H.L.; Wheeler, M.H 14

Restorative Proctocolectomy with Heal Reservoir and Ileoanal

Anastomosis for Ulcerative Colitis and Familial Polyposis

Rothenberger, D.A.; Wong, W.D.; Buls, J.G.; Goldberg,

S.M.; Christenson, C.E

Intraoperative Assessment of the Proximal Gastric Vagotomy

Completeness by a Simple $\mathrm{pH}$ Test

Narbona, B.; Olavarrieta, L.; Villalba, S.; Lloris, J.M.; Nar-

bona-Calvo, B 27

Impact of Early Operation on the Mortality from Bleeding Peptic Ulcer

Röher, H.-D.; Thon, K

32

Emergency One-Stage Subtotal Colectomy with Anastomosis

for Obstructing Carcinoma of the Left Colon

Adloff, M.; Arnaud, J.P.; Oilier, J.C 37

Postoperative Small Bowel Transit Time Evaluated by Breath

Hydrogen Measurement

Hubens, A.; Creve, U.; Van Rooy, F 41

Adenocarcinoma of the Appendix. A Plea for Right Hemicolec-

tomy

Guivarc'h, M 45

Benefits of Regular Documentation of Wound Infection and

Complication Rates after Gastric and Colon Resection

Grundmann, R.; Reimer, P.; Pichlmaier, H 50

Progress Report 
The Peroperative Use of Real-Time B-Mode Ultrasound Imag ing in Biliary and Pancreatic Surgery

Jakimowicz, J.J.; Carol, E.J.; Jürgens, P.T.H.J 55

C.I.C.D.

Collegium Internationale Chirurgiae Digestivae

8th World Congress Amsterdam, September 11-14, 1984 Abstracts

No. 4

Original Paper

Intraoperative Radiation for Unresectable Carcinoma of the

Pancreas (With 1 color plate)

Nardi, G.L.; Tepper, J.E.; Shipley, W.U 165

Surgical Management of Villous Tumors of the Colon and

Rectum

Malafosse, M.; Roge, P 168

Biliary Complications of Chronic Pancreatitis. The Place of Bil iary-Enteric Bypass in Surgical Treatment

Sarles, J.C; Nacchiero, M.; Leandri, R 172

Stapling Technique for Ileoanal Anastomosis with Heal Reser voir after Proctocolectomy

Bérard, P 176

Growth Enhancement of Hepatocellular Carcinoma in the Rat after Portacaval Shunt

Wei, W.I.; Wong, J.; Ong, G.B 180

Supercontinence following Antireflux Surgery - Evaluation by pH-Metry

Weiser, H.F.; Wu, Y.Q.; Siewert, J.R 185

Ileorectal Anastomosis in Ulcerative Colitits

Gallot, D.; Malafosse, M 190

Portal Bacteremia in Acute Cholecystitis

Wählby, L.; Claesson, B 193

Reversible End-Ileostomy, with Its Sphincter, as Complemen tary Procedure in Surgical Treatment of Severe Intestinal

Occlusion

Palma,E.C 196

Transrectal Sonography and Endoscopic Lymphoscintigraphy in the Preoperative Staging of Rectal Cancer

Montori, A.; Miscusi, G.; Saracca, L.; DelГAnna, A.; Cio-

fetta, G.; Risa, L; Barbarossa, C 200

IV

Contents

Prolonged Surgical Transtumoral Intubation of the Biliary

Tract. A Palliative Treatment of Malignant Obstruction

Jaundice

Stoppa, R.E.; Henry, X.F.; Verhaeghe, P.J 205

Gastro-Oesophageal Reflux in Italian Healthy Volunteers and 
Patients: Relationship between Gastro-Oesophageal Reflux, Endoscopic Oesophagitis and Symptoms

Zaninotto, G.; Merigliano, S.; Baessato, M.; Costantini, M.;

Nosadini, A.; Sorrentino, P.; Pianalto, S.; Ancona, E. ... 211 A Peroperative Pressure

Measurement in the Biliary Tract

Using the Microtransducer Catheter

Carol, E.J.; Jakimowicz, J.J 217

Infected Pancreatic Pseudocyst with Biliary Fistula

Pattison, C.W.; Downing, R 222

Progress Report

Development and Characterization of 51 Human Tumor Mod

els for Large Bowel, Stomach and Esophageal Cancers

Fiebig, H.H.; Widmer, K.-H.; Fiedler, L.; Wittekind, C;

Löhr,G.W 225

Author Index 236

Subject Index 236 